\title{
PENGARUH SUPLEMENTASI VITAMIN D TERHADAP NILAI PENGUKURAN FEV1/ FVC PADA PENDERITA ASMA TERKONTROL SEBAGIAN
}

\author{
Adyan Donastin ${ }^{1}$, Arief Bakhtiar², Daniel Maranatha ${ }^{3}$ \\ PPDS-I Pulmonologi dan Ilmu Kedokteran Respirasi \\ FK UNAIR-RSUD Dr. Soetomo 1 \\ Staf Pengajar Pulmonologi dan Ilmu Kedokteran Respirasi
}

\begin{abstract}
Background:Airflow resistance in asthma caused by changes in the airways that is bronchoconstriction, airway edema, airway hyperresponsiveness and airway remodeling. Vitamin D supplementation is expected to raise the value of the measurement of FEV1/ FVC in patients with asthma controlled in part through the role of vitamin D in terms of antiviral effects, atopic response, response improvement steroid and prevent airway remodeling process.Objective:Comparing the measurement values of FEV1/ FVC in patients with asthma controlled most of which do not get supplemental vitamin D than getting supplemental vitamin D.Methods:This study is a randomized experimental simple study. This research was conducted in $\mathrm{dr}$ Soetomo Hospital from June to July 2015. The sampling technique using consecutive sampling. Samples were divided into two groups each consisting of 14 samples which have earned a combined therapy of inhaled corticosteroids and LABA. The control group that was not given additional vitamin D supplementation and the treatment group were given supplements of vitamin D for 1 month. Measurement and main result:Testing of data distribution using the ShapiroWilk method because the sample size is less than 50. The result of the difference in FEV1 / FVC with a paired sample $\mathrm{t}$ - test is known that in the control group (not given additional vitamin D supplements) did not occur significant difference $(p=0.219>0.05)$, while the treatment group (given additional vitamin supplements $\mathrm{D})$ proved significant difference $(\mathrm{p}=0.020$ $<0.05$ ) where the value of FEV1 / FVC after being given additional vitamin D supplements increased to $96.071 \%$ of the initial conditions is $84.786 \%$.Conclusions: The measurement values of FEV1/ FVC in patients with asthma controlled most of which get vitamin D supplementation are the most significant increase compared to the control group who did not receive supplementation ofvitamin D.
\end{abstract}

Keywords: partial controlled asthma, vitamin D, FEV1/ FVC

\section{PENDAHULUAN}

Asma adalah penyakit saluran napas kronik merupakan masalah kesehatan masyarakat di berbagai negara yang dapat menurunkan produktivitas akibat mangkir kerja atau sekolah dan dapat menimbulkan disability (kecacatan), sehingga menambah penurunan produktivitas serta menurunkan kualitas hidup.1Penyakit asma di Indonesia ini termasuk peringkat 10 besar penyebab kematian dan kesakitan dengan tingkat prevalensi 6 - 8\%.Data Riset Kesehatan Dasar (Riskesdas) tahun 2007 prevalensi penyakit asma mencapai 4\% dimana angka ini jauh di atas prevalensi asma pada tahun 1995 menurut Survei Kesehatan Rumah Tangga (SKRT) yang hanya 1,3\%. (PDPI.2010, GINA. 2014, CDC. 2001-2004, RISKESDAS 2007)

Asma adalah gangguan inflamasi kronik saluran napas yang melibatkan banyak sel dan elemennya sertamenyebabkan penurunan faal paru seiring dengan bertambahnya usia.1,5,6Suplementasi vitamin D diharapkan dapat menaikkan nilai FEV1/FVCsebagai parameter derajat obstruksi pada penderita asma terkontrol sebagian melalui peran vitamin D dalam hal efek antiviral, respons atopi, perbaikan respons steroid dan mencegah proses airway remodeling. 


\section{METODE PENELITIAN}

Penelitian bersifat eksperimental yang dilakukan di Poli Asma Dept/SMF Pulmonologi dan Ilmu Kedokteran Respirasi RSUD dr Soetomo Surabaya.Waktu penelitian 4 minggu.Sampel penelitian adalah penderita asma terkontrol sebagian yang berobat ke instalasi rawat jalan (Poli asma) Dept/SMF Pulmonologi dan Ilmu Kedokteran Respirasi RSUD dr Soetomo Surabaya selama periode penelitian yang memenuhi kriteria inklusi (penderita asma terkontrol sebagian, lakilaki atau perempuan) 16 th, sedang mendapatkan terapi kombinasi bronkodilator dan steroid inhalasi, bersedia sebagai subyek penelitian dan menandatangani "informed consent"dan eksklusi (penderita asma dalam serangan, alergi vitamin D, sedang mengkonsumsi suplemen vitamin D).

Jumlah sampel untuk tiap kelompok adalah 14 orang, diambil dari penderita rawat jalan di Poli asma RSUD dr. Soetomo yang telah memenuhi kriteria dengan menggunakan consecutive sampling. Analisisdata menggunakan SPSS 15.0 Analisis yang digunakan untuk menguji hipotesis dilakukan uji t-berpasangan (paired T-test).Bahan penelitian yang digunakan adalah spirometer (Spiroanalyzer ST-75 merk Fukuida Sangyo), lembar kuesioner asthma control test (ACT), tablet kombinasi kalsium dengan vitamin $\mathrm{D}$ dan lembar pengumpul data. Pemeriksaan ACT dilakukan dengan menjawab pertanyaan yang tercantum dalam lembar ACT.Pengukuran FEV1/ FVC dilakukan dengan meletakkan mouth piece dari alat spirometer.

\section{HASIL PENELITIAN}

\section{PROFIL SUBYEK PENELITIAN}

Hasil deskripsi untuk profil sampel pasien diketahui bahwa berdasarkan jenis kelamin pada kelompok kontrol laki-laki 21,4\%,perempuan78,6\% sedangkan pada kelompok perlakuan laki-laki $35,7 \%$, perempuan $64,3 \%$.
Sebagian besar adalah perempuan baik pada kelompok kontrol maupun perlakuan dengan prosentase $64 \%$ hingga $78 \%$. Pendidikan sampel pasien diketahui sebagian besar adalah SMA dan S1 baik pada kelompok kontrol maupun kelompok perlakuan dengan jumlah mencapai 21 orang (75\%) dari 28 sampel.Profesi pasien bervariasi yang dikelompokkan menjadi berprofesi sebagai pegawai, pedagang, penitipan anak, ibu rumah tangga. Kebanyakan yang berprofesi sebagai ibu rumah tangga (46,4\%). Profil yang menunjukkan bahwa umur pasien yang menjadi sampel pada kelompok kontrol dengan median 44 tahun sedangkan pada kelompok perlakuan dengan median 44,5 tahun.Berat badan pada kelompok kontrol mempunyai median $60,5 \mathrm{~kg}$ sedangkan pada kelompok perlakuan mempunyai median $62,5 \mathrm{~kg}$ sedangkan berat badan rata-rata pada kedua kelompok $60 \mathrm{~kg}$. Tinggi badan pada kelompok kontrol mempunyai median $154,5 \mathrm{~cm}$ sedangkan pada kelompok perlakuan mempunyai median 157 $\mathrm{cm}$. Indeks massa tubuh pada kelompok kontrol mempunyai median 24,8 sedangkan pada kelompok perlakuan mempunyai median 24,66 .

\section{DISTRIBUSI HASIL PEMERIKSAAN SPIROMETRI}

Hasil pemeriksaan klinis untuk nilai FEV1 pada penderita asma terkontrol sebagian yang telah mendapatkan terapi kombinasi inhalasi kortikosteroid dan LABA pada kondisi sebelum dan sesudah pemberian suplemen vitamin D kelompok kontrol dan perlakuan adalah sebagai berikut: 
Tabel Distribusi Nilai FEV1 Pasien Sampel

\begin{tabular}{|c|c|c|c|}
\hline Variabel & Kelompok & Kondisi & Ukuran Klinis (\%) \\
\hline \multirow{4}{*}{$\begin{array}{l}\mathrm{FEV}_{1} / \mathrm{FVC} \\
\quad \text { Rerata } \pm \text { St. Dev } \\
\text { (Min - Maks) }\end{array}$} & \multirow{2}{*}{ Kontrol } & Pre & $\begin{array}{l}67,329 \pm 11,563 \\
(51 \mathrm{~s} / \mathrm{d} 84)\end{array}$ \\
\hline & & Post & $\begin{array}{l}63,936 \pm 10,226 \\
(41 \mathrm{~s} / \mathrm{d} 76)\end{array}$ \\
\hline & \multirow{2}{*}{ Perlakuan } & Pre & $\begin{array}{l}60,571 \pm 11,001 \\
(43 \mathrm{~s} / \mathrm{d} 87)\end{array}$ \\
\hline & & Post & $\begin{array}{l}66,329 \pm 14,381 \\
(43 \mathrm{~s} / \mathrm{d} 102)\end{array}$ \\
\hline
\end{tabular}

Hasil dari pemeriksaan pada nilai FEV1 penderita asma terkontrol sebagian yang telah mendapatkan terapi kombinasi inhalasi kortikosteroid dan LABA baik pada kelompok kontrol maupun kelompok perlakuan cenderung mengalami kenaikan nilai FEV1, apabila diperhatikan ukuran keragaman pada kelompok perlakuan yang diberikan tambahan suplemen vitamin D relatif lebih kecil dibandingkan kelompok kontrol yang tidak diberikan tambahan suplemen vitamin D.Selisih kenaikan nilai FEV1 pada pemeriksaan sebelum dan sesudah pada kelompok perlakuan yang diberi tambahan suplemen vitamin tercatat juga lebih besar mengalami peningkatan dibandingkan dengan kelompok kontrol didapatkan nilai rentang yang turun sebesar 34-160 (\%) pada post kelompok kontrol FEV1 dibandingkan pre pada kelompok kontrol FEV1 53-150 (\%).

Hasil pemeriksaan klinis untuk nilai FVC pada penderita asma terkontrol sebagian yang telah mendapatkan terapi kombinasi inhalasi kortikosteroid dan LABA pada kondisi sebelum dan sesudah pemberian suplemen vitamin D kelompok kontrol dan perlakuan adalah sebagai berikut.

Tabel Distribusi Nilai FVC Pasien Sampel

\begin{tabular}{|c|c|c|c|}
\hline Variabel & Kelompok & Kondisi & Ukuran Klinis (\%) \\
\hline \multirow{4}{*}{$\begin{array}{l}\text { FVC } \\
\text { Rerata } \pm \text { St. Dev } \\
\text { (Min - Maks) }\end{array}$} & \multirow[b]{2}{*}{ Kontrol } & Pre & $\begin{array}{l}114,929 \pm 28,234 \\
(48 \mathrm{~s} / \mathrm{d} 157)\end{array}$ \\
\hline & & Post & $\begin{array}{l}114,857 \pm 31,703 \\
(43 \mathrm{~s} / \mathrm{d} 167)\end{array}$ \\
\hline & \multirow{2}{*}{ Perlakuan } & Pre & $\begin{array}{l}118,643 \pm 20,048 \\
(100 \mathrm{~s} / \mathrm{d} 174)\end{array}$ \\
\hline & & Post & $\begin{array}{l}125,357 \pm 19,716 \\
(88 \mathrm{~s} / \mathrm{d} 173)\end{array}$ \\
\hline
\end{tabular}

Hasil dari pemeriksaan pada nilai FVC penderita asma terkontrol sebagian yang telah mendapatkan terapi kombinasi inhalasi kortikosteroid dan LABA pada kelompok perlakuan cenderung mengalami kenaikan nilai FVC, sementara pada kelompok kontrol agak sedikit mengalami penurunan.
Didapatkan nilai rentang yang turun sebesar 88-173 (\%) pada kelompok perlakuan FVC post pemberian vitamin D dibandingkan kelompok perlakuan pre pemberian vitamin D 100-174 (\%). Ukuran keragaman pada kelompok perlakuan yang diberikan tambahan suplemen vitamin D relatif 
lebih kecil dibandingkan kelompok kontrol yang tidak diberikan tambahan suplemen vitamin D.

Selisih kenaikan nilai FVC pada pemeriksaan sebelum dan sesudah pada kelompok perlakuan yang diberi tambahan suplemen vitamin tercatat juga lebih besar mengalami peningkatan dibandingkan dengan kelompok kontrol.
Hasil pemeriksaan klinis untuk nilai FEV1/FVC pada penderita asma terkontrol sebagian yang telah mendapatkan terapi kombinasi inhalasi kortikosteroid dan LABA pada kondisi sebelum dan sesudah pemberian suplemen vitamin D kelompok kontrol dan perlakuan adalah sebagai berikut:

Tabel Distribusi Nilai FEV1/FVC Pasien Sampel

\begin{tabular}{|c|c|c|c|}
\hline Variabel & Kelompok & Kondisi & Ukuran Klinis (\%) \\
\hline \multirow{4}{*}{$\begin{array}{l}\mathrm{FEV}_{1} / \mathrm{FVC} \\
\text { Rerata } \pm \text { St. Dev } \\
(\text { Min - Maks })\end{array}$} & \multirow{2}{*}{ Kontrol } & Pre & $\begin{array}{l}67,329 \pm 11,563 \\
(51 \mathrm{~s} / \mathrm{d} 84)\end{array}$ \\
\hline & & Post & $\begin{array}{l}63,936 \pm 10,226 \\
(41 \mathrm{~s} / \mathrm{d} 76)\end{array}$ \\
\hline & \multirow{2}{*}{ Perlakuan } & Pre & $\begin{array}{l}60,571 \pm 11,001 \\
(43 \mathrm{~s} / \mathrm{d} 87)\end{array}$ \\
\hline & & Post & $\begin{array}{l}66,329 \pm 14,381 \\
(43 \mathrm{~s} / \mathrm{d} 102)\end{array}$ \\
\hline
\end{tabular}

Hasil dari pemeriksaan pada nilai FEV1/FVC penderita asma terkontrol sebagian yang telah mendapatkan terapi kombinasi inhalasi kortikosteroid dan LABA pada kelompok perlakuan yang diberikan tambahan suplemen vitamin D cenderung mengalami kenaikan nilai FEV1/FVC, sedangkan untuk kelompok kontrol mengalami penurunan nilai FEV1/FVC. Didapatkan nilai rentang yang turun pada kelompok kontrol FEV1/ FVC sebesar 41-76 (\%) pada kelompok post dibandingkan kelompok pre sebesar 51-84 (\%). Secara grafik dapat ditampilkan sebaran distribusi nilai FEV1/ FVC sebagai berikut:

\section{PENGUJIAN SEBARAN DATA}

Pengujian sebaran data dilakukan untuk mengetahui tingkat penyebaran dari data penelitian yang akan dipergunakan. Hasil dari pengujian sebaran data nantinya akan dipergunakan untuk menentukan metode uji beda yang akan dipakai. Untuk penelitian ini pengujian sebaran data dilakukan dengan metode Shapiro Wilk karena jumlah sampel yang ada masih lebih kecil dari 50.

Ketentuan hasilnya adalah apabila nilai probabilitas ( $p$-value) Shapiro wilk untuk tiap kelompok sampel dan ukuran klinis sudah lebih besar dari tingkat kemaknaan 5\% $(0,05)$ maka disimpulkan sebaran data penelitian sudah menyebar normal dan untuk pengujian beda dapat menggunakan uji statistik parametrik paired sample t-test. Sementara itu, apabila nilai probabilitas, (pvalue) Shapiro wilk untuk tiap kelompok sampel dan ukuran klinis ada yang lebih kecil dari tingkat kemaknaan 5\% $(0,05)$ maka disimpulkan sebaran data penelitian masih belum menyebar normal dan untuk pengujian beda akan digunakan uji statistik non parametrik wilcoxon sign rank test.

\section{UJI BEDA BERPASANGAN}

Uji beda berpasangan dalam penelitian dipergunakan untuk membuktikan bahwa dengan penambahan vitamin D pada pasien akan menaikkan kadar FEV1, FVC dan FEV1/FVC pada pasien asma terkontrol sebagian yang telah mendapatkan terapi kombinasi inhalasi kortikosteroid dan LABA.

Berdasarkan hasil pengujian sebaran data disimpulkan bahwa untuk melakukan uji perbedaan akan dilakukan dengan metode paramaterik paired sample t-test terkecuali untuk ukuran klinis FVC (Pre - Post) pada kelompok perlakuan dimana masih terdapat sebaran datanya yang belum menyebar menurut sebaran normal sehingga harus menggunakan uji statistik non parametrik wilcoxon 
sign rank test. Hasil uji beda selengkapnya dapat ditabelkan sebagai berikut:

Hasil uji perbedaan pada nilai FEV1 dengan paired sample $\mathrm{t}$ - test diketahui bahwa pada kelompok kontrol (tidak diberikan suplemen tambahan vitamin D) tidak terjadi perbedaan bermakna $(p=0,502>0,05)$, sementara pada kelompok perlakuan (diberikan suplemen tambahan vitamin D) terbukti terdapat perbedaan yang bermakna $(\mathrm{p}=0,007<0,05)$ dimana nilai FEV1 setelah diberikan suplemen tambahan vitamin D mengalami kenaikan menjadi 96,071\% dari kondisi awal yaitu $84,786 \%$.

Hasil uji perbedaan pada nilai FVC dengan paired sample $\mathrm{t}$ - test (kontrol) dan wilcoxon sign rank test (perlakuan) diketahui juga bahwa untuk kelompok kontrol (tidak diberikan suplemen tambahan vitamin D) disimpulkan tidak terjadi perbedaan bermakna $(p=0,992>0,05)$, sementara pada kelompok perlakuan (diberikan suplemen tambahan vitamin D) terbukti terdapat perbedaan yang bermakna $(\mathrm{p}=0,028<0,05)$, didapatkan nilai FVC setelah diberikan suplemen tambahan vitamin D mengalami kenaikan menjadi $128 \%$ dari kondisi awal yaitu $114,857 \%$.

Hasil uji perbedaan pada nilai FEV1/FVC dengan paired sample $\mathrm{t}$ - test diketahui bahwa pada kelompok kontrol (tidak diberikan suplemen tambahan vitamin D) tidak terjadi perbedaan bermakna $(\mathrm{p}=0,219>0,05)$, sementara pada kelompok perlakuan (diberikan suplemen tambahan vitamin D) terbukti terdapat perbedaan yang bermakna $(\mathrm{p}=0,020<0,05)$ dimana nilai FEV1/FVC setelah diberikan suplemen tambahan vitamin D mengalami kenaikan menjadi 96,071 \%dari kondisi awal yaitu 84,786\%.

\section{UJI BEDA DUA KELOMPOK SAMPEL INDEPENDEN}

Untuk mengetahui bahwa perubahan yang terjadi pada FEV1 dan FEV1 / FVC kelompok pasien yang diberikan vitamin $\mathrm{D}$ cenderung positif atau mengalami kenaikan berikut akan ditampilkan hasil uji delta FEV1 dan FEV1 / FVC pada kondisi pre dan post test:

Hasil pengujian ditribusi data delta FEV1 dan FEV1/FVC pada kelompok kontrol dan perlakuan diperoleh nilai p-value uji yang kesemuanya bernilai lebih besar dari tingkat kemaknaan 0,05 $(0,254 ; 0,579 ; 0,858$; dan 0,944). Hal ini berarti distribusi data untuk delta FEV1 dan FEV1/FVC telah menyebar menurut sebaran normal. Dengan demikian pengujian perbedaan delta FEV1 dan FEV1/FVC akan digunakan uji independent sample t-test.

Hasil uji perbedaan pada nilai delta FEV1 pada kelompok kontrol dan kelompok perlakuan dengan independent sample $\mathrm{t}$ - test diketahui tidak terjadi perbedaan bermakna $(\mathrm{p}=0,704>0,05)$. Walaupun tidak terdapat perbedaan yang bermakna delta FEV1 akan tetapi secara rerata dapat dilihat bahwa nilai perubahan FEV1 pada kelompok pasien yang diberikan perlakuan vitamin $\mathrm{D}$ cenderung lebih besar $(11,60)$ dibandingkan dengan nilai pada kelompok kontrol $(5,71)$. Hasil ini menunjukkan bahwa perlakuan vitamin D memberikan perubahan nilai FEV 1 yang lebih positif dibandingkan kelompok pasien yang tidak diberikan vitamin $\mathrm{D}$.

Hasil uji perbedaan pada nilai delta FEV1 / FVC pada kelompok kontrol dan kelompok perlakuan dengan independent sample $\mathrm{t}$ - test diketahui tidak terjadi perbedaan bermakna $(p=0,142>0,05)$. Walaupun tidak terdapat perbedaan yang bermakna delta FEV1/FVC akan tetapi secara rerata dapat dilihat bahwa nilai perubahan FEV1/FVC pada kelompok pasien yang diberikan perlakuan vitamin D cenderung lebih besar $(5,05)$ dibandingkan dengan nilai pada kelompok kontrol $(0,35)$. Hasil ini menunjukkan bahwa perlakuan vitamin D memberikan perubahan nilai FEV1/FVC yang lebih positif dibandingkan kelompok pasien yang tidak diberikan vitamin $\mathrm{D}$.

\section{PEMBAHASAN}

\section{DISTRIBUSI HASIL PEMERIKSAAN SPIROMETRI}

Hasil dari pemeriksaan spirometri nilai FEV1, FVC maupun FEV1/FVC penderita asma terkontrol sebagian yang telah mendapatkan terapi kombinasi inhalasi kortikosteroid dan LABA pada kelompok perlakuan yang menggunakan suplementasi vitamin D cenderung mengalami kenaikan dan apabila diperhatikan ukuran keragaman pada kelompok perlakuan yang diberikan tambahan suplemen vitamin $\mathrm{D}$ relatif lebih kecil dibandingkan 
kelompok kontrol yang tidak diberikan tambahan suplemen vitamin D. Hasil ini sesuai dengan hasil penelitian Abolfazl dan Black yang menunjukkan bahwa kadar vitamin D yang cukup akan memperbaiki fungsi paru.11,12

Hasil uji perbedaan pada nilai FEV1 dengan paired sample $\mathrm{t}$ - test diketahui bahwa pada kelompok kontrol (tidak diberikan suplemen tambahan vitamin D) tidak terjadi perbedaan bermakna $(p=0,502>0,05)$, sementara pada kelompok perlakuan (diberikan suplemen tambahan vitamin D) terbukti terdapat perbedaan yang bermakna $(p=0,007<0,05)$. Nilai rentang FEV1 pada kelompok kontrol post dibandingkan pre terdapat penurunan, hasil ini menunjukkan bahwa tanpa suplementasi vitamin D pada kelompok kontrol terjadi penurunan faal paru pada sebagian sampel.Hasil uji perbedaan pada nilai delta FEV1 pada kelompok kontrol dan kelompok perlakuan dengan independent sample $\mathrm{t}$ - test diketahui tidak terjadi perbedaan bermakna $(p=0,704>0,05)$. Walaupun tidak terdapat perbedaan yang bermakna delta FEV1 akan tetapi secara rerata dapat dilihat bahwa nilai perubahan FEV1 pada kelompok pasien yang diberikan perlakuan vitamin $\mathrm{D}$ cenderung lebih besar $(11,60)$ dibandingkan dengan nilai pada kelompok kontrol $(5,71)$. Hasil ini menunjukkan bahwa perlakuan vitamin D memberikan perubahan nilai FEV 1 yang lebih positif dibandingkan kelompok pasien yang tidak diberikan vitamin D.Penelitian Abolfazl,Willemien dkk juga melaporkan bahwa terjadi peningkatan nilai FEV1 setelah pemberian suplementasi vitamin D.11,13 Berdasarkan teori dikatakan bahwa kadar vitamin D yang cukup akan memperbaiki fungsi paru, menurunkan eksaserbasi asma dan menurunkan angka perawatan di rumah sakit. Vitamin D mempunyai peran menurunkan faktor atopi, meningkatkan aktivitas makrofag, memperbaiki resistensi steroid pada asma dan mencegah airway remodeling.7,8,9,10

Hasil uji perbedaan pada nilai FVC dengan paired sample $\mathrm{t}$ - test (kontrol) dan wilcoxon sign rank test (perlakuan) diketahui juga bahwa untuk kelompok kontrol (tidak diberikan suplemen tambahan vitamin D) disimpulkan tidak terjadi perbedaan bermakna $(p=0,992>0,05)$, sementara pada kelompok perlakuan (diberikan suplemen tambahan vitamin D) terbukti terdapat perbedaan yang bermakna $(p=0,028<0,05)$. Hasil ini sesuai hasil penelitian Rodolfo yang melaporkan bahwa kadar vitamin D yang cukup pada penderita asma menunjukkan hasil pemeriksaan faal paru yang normal dan memperbaiki fungsi paru, salah satu parameter yang diukur adalah FVC yang normal.11,13,14 Didapatkan nilai rentang 88-173 (\%) pada kelompok perlakuan FVC post pemberian vitamin D dibandingkan kelompok perlakuan pre pemberian vitamin D 100-174, hasil ini menunjukkan bahwa terdapat sampel pada kelompok perlakuan setelah mendapatkan suplementasi vitamin D selama 1 bulan justru nilai FVC menurun. Meskipun demikian apabila diperhatikan ukuran keragaman pada kelompok perlakuan yang diberikan tambahan suplemen vitamin D relatif lebih kecil dibandingkan kelompok kontrol yang tidak diberikan tambahan suplemen vitamin D. Selisih kenaikan nilai FVC pada pemeriksaan sebelum dan sesudah pada kelompok perlakuan yang diberi tambahan suplemen vitamin tercatat juga lebih besar mengalami peningkatan dibandingkan dengan kelompok kontrol.

Hasil uji perbedaan pada nilai FEV1/FVC dengan paired sample $\mathrm{t}$ - test diketahui bahwa pada kelompok kontrol (tidak diberikan suplemen tambahan vitamin D) tidak terjadi perbedaan bermakna $(p=0,219>0,05)$, sementara pada kelompok perlakuan (diberikan suplemen tambahan vitamin D) terbukti terdapat perbedaan yang bermakna $(p=0,020<0,05)$. Didapatkan nilai rentang yang turun pada kelompok kontrol FEV1/ FVC sebesar 41-76 (\%) pada kelompok post dibandingkan kelompok pre sebesar 51-84 (\%), hasil ini menunjukkan bahwa pada kelompok kontrol yang tanpa mendapatkan suplementasi vitamin D terdapat penurunan hasil faal paru.Hasil uji perbedaan pada nilai delta FEV1/FVC pada kelompok kontrol dan kelompok perlakuan dengan independent sample $\mathrm{t}$ - test diketahui tidak terjadi perbedaan bermakna $(\mathrm{p}=0,142>0,05)$. Walaupun tidak terdapat perbedaan yang bermakna pada delta FEV1/FVC akan tetapi secara rerata dapat dilihat bahwa nilai perubahan FEV1/FVC pada kelompok pasien yang diberikan perlakuan vitamin D cenderung lebih besar $(5,05)$ dibandingkan dengan nilai pada kelompok kontrol (0,35). Hasil ini menunjukkan bahwa perlakuan vitamin D memberikan perubahan nilai FEV1/FVC yang lebih 
positif dibandingkan kelompok pasien yang tidak diberikan vitamin D. Hasil ini sesuai dengan hasil penelitian Black dan Rodolfo bahwa suplementasi vitamin D yang cukup akan memperbaiki fungsi paru yang dinilai dari pengukuran FEV1/FVC.12,14

Didapatkan nilai pengukuran rasio FEV1/FVC dibawah 70\% pada kelompok kontrol maupun perlakuan yang mengesankan adanya PPOK pada sampel penelitian. Hal ini sebelumnya telah diantisipasi oleh peneliti melalui kuesioner yang diberikan untuk menyingkirkan kemungkinan PPOK dengan menanyakan riwayat merokok dan hasil pemeriksaan foto toraks. Kemungkinan hasil rasio FEV1/FVC yang didapatkan ini bisa disebabkan keterlambatan pasien untuk kontrol sehingga dalam beberapa hari tidak menggunakan bronkodilator, manuver pemeriksaan yang kurang tepat dan faktor kelelahan pasien dari poli asma menuju ke poli paru untuk pemeriksaan faal paru.

\section{EFEK SAMPING DAN KEAMANAN OBAT}

Selama penelitian berlangsung tidak didapatkan efek samping dari vitamin D yang berupa reaksi alergi maupun gangguan pencernaan.

\section{KETERBATASAN PENELITIAN}

1. Pada penelitian ini tidak dilakukan pemeriksaan kadar vitamin D dalam serum sebelum dan sesudah perlakuan.

2. Tidak dilakukan tes reversibilitas pada sampel penelitian.

\section{KESIMPULAN}

Nilai pengukuran FEV1/ FVC penderita asma terkontrol sebagian yang mendapatkan terapi kombinasi ICS dan LABA dengan ditambahkan suplemen vitamin D didapatkan peningkatan yang bermakna dibandingkan yang tidak mendapatkan suplementasi vitamin D.Dengan demikian pemberian suplemen vitamin D dapat dipertimbangkan pada penderita asma untuk memperbaiki fungsi paru.

\section{DAFTAR PUSTAKA}

Perhimpunan Dokter Paru Indonesia (PDPI). Asma. Pedoman diagnosis dan piñata laksanaan di Indonesia 2010.

Global Initiative for Asthma (GINA). Global Strategy for Asthma Management and Prevention. Revised 2014.

Centers for Disease Control and Prevention (CDC). Vital signs: asthma prevalence, disease characteristic and self-management education --United States, 2001 - 2009. Morbidity and mortality weekly report. 2011; 60(17): 547-52.

Depkes RI. Riset kesehatan dasar. RISKESDAS 2007. Jakarta: Departemen Kesehatan, Republik Indonesia. 2008.

Xystrakis E, Kusumakar S, Boswell S, et al. Reversing the defective induction of IL-10 secreting regulatory $\mathrm{T}$ cells in glucocorticoid-resistant asthma patients. J Clin Invest. 2006, 116:146-155.

Akdis $\mathrm{M}$, Verhagen $\mathrm{J}$, Taylor $\mathrm{A}$, et al. Immune responses in healthy and allergic individuals are characterized by a fine balance between allergen-specific $\mathrm{T}$ regulatory 1 and $\mathrm{T}$ helper 2 cells. J Exp Med. 2004, 199:1567-1575.

Hyppönen E, Berry DJ, Wjst M, et al. Serum 25hydroxyvitamin D and IgE - a significant but nonlinear relationship. Allergy. 2009 Apr;64(4):613-620.

Cynthia Aranow. Vitamin D and the Immune System. J Investig Med. 2011 August ; 59(6): 881-886.

Sutherland ER, Goleva E, Jackson LP, et al. Vitamin D levels, lung function, and steroid response in adult asthma. Am J Respir Crit Care Med. 2010 Apr;1;181(7):699-704 
Banerjee A, Damera G, Bhandare R et al. Vitamin d and glucocorticoids differentially modulate chemokine expression in human airway smooth muscle cells. Br J Pharmacol. 2008; 155: 84 - 92 .

Abolfazl Zendedel, Mohammadreza Gholami, Khatereh Anbari et al. Effects of Vitamin D Intake on FEV1 and COPD Exacerbation: A randomized clinical trial study. Global Journal of Health Science; Vol. 7, No. 4; 2015.

Black PN, Scragg R. Relationship between serum 25-hydroxyvitamin $\mathrm{d}$ and pulmonary function in the third national health and nutrition examination survey. Chest. 2005 Dec;128(6):3792-8.
Ms. Willemien, Mr. Robert, Frits et al. The association between vitamin D and FEV1 in a general population is not explained by eNO. European Respiratory SocietyAnnual Congress 2013.

Rodolfo M, Wendy C, Stephen P et al. Serum Vitamin D Levels Are Inversely Correlated With FEV1 and FVC in asthma. Am J Respir Crit Care Med 181: 2010. 